\title{
TRADITIONAL WEAPON KUJANG MASTERPIECE OF INDONESIA
}

\author{
By : \\ Endang Naryono \\ Lecturer of the Pasim College of Economics \\ rtumarima@gmail.com
}

\begin{abstract}
ION
West Java in ancient times called Pasundan was a large area for Sunda known as the Pajajaran Kingdom led by Prabu Dewataprana Sri Baduga Maharaja or Jayadewata who was better known to the wider community by the name Prabu Siliwangi. At that time the Sunda Hindu Kingdom was in crisis because of the influence of Islam brought by Indian Gujarat merchants. So that Prabu Siliwangi made an ancient literary text as a way of life for the Sundanese people. Reporting from Wikipedia, Prabu Siliwangi made a life guide book called Sanghyang Siksa Kandang Karesian in 1518 as a provision for community life in Pajajaran. The book contains various kinds of norms, morals, culture, customs, to the typical arts of Pajajaran. One of the traditional weapons listed in the ancient text is the cleaver.
\end{abstract}

Keywords: Kujang, Pajajaran, Prabu Siliwangi

\section{A. INTRODUCTION}

Kujang has a very long historical background with the process of its creation which has been widely studied in previous research. Based on the evidence that has been found, many of the cleavers were created during the Pajajaran kingdom. There is even a mention that the cleaver existed during the Tarumanegara kingdom. Although the name of the cleaver was never written in the inscription, there is a lot of evidence that supports its existence, such as the Batu Kujang megalithic site in the Sukabumi area, the discovery of kudi in the Batujaya Karawang temple complex, the reliefs of the Sukuh temple in Surakarta, the notes of Stamford Raffles in the book "History of Java". , etc.

In the archipelago in general, the "Kudi" tool is known as a weapon for hunting and as a cutting tool. Kudi is found in various regions in Indonesia, including the islands of Alor, Java, Madura, Bali, Sumatra, Sulawesi, and Kalimantan. On the island of Madura, the kudi evolved into a weapon that we now know as "celurit". While on the island of Java in general, kudi evolved into a form of tool called bendo sickle (kudi bendo) or sickle. Since the days of the Javanese Hindu kingdom, the masters or blacksmiths in Indonesia have made kudi as a tool, then in West Java itself the kudi developed a special form, becoming what we know as "cleaver".

Kujang is a weapon that has sacred and mystical values and is useful as a means of ritual. In general, the deer has an understanding as an heirloom that has aesthetic values that have symbolic and philosophical meaning of Sundanese culture, where these values and meanings have a certain mystical power that comes from Hyang Tunggal. As an heirloom, the cleaver has always had a special position specifically in Sundanese society, not as a weapon, nor as a tool used for people's daily activities. Kujang functions as 
spiritual objects or better known as heirlooms and talismans. Another function is as a mystical medium, a status symbol, and a talisman

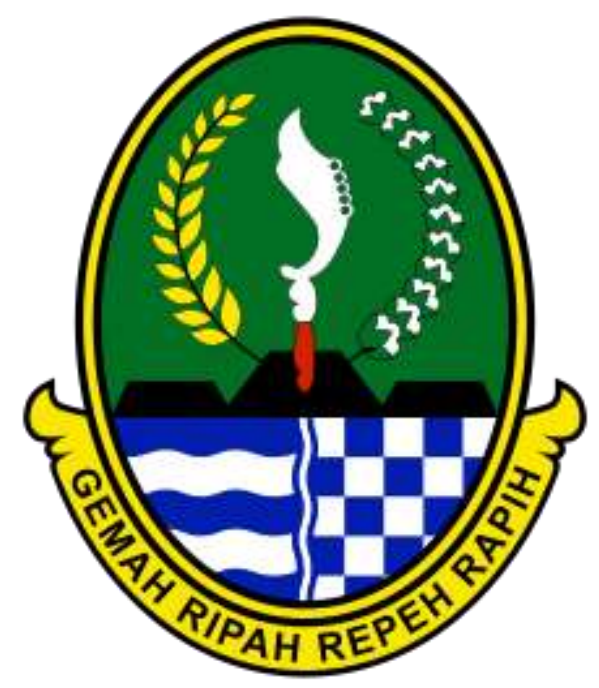

Source: Wikipedia

Kujang Symbol of West Java Province

The name "Kujang" comes from the words Ku Jawa Hyang or Ku Dyah Hyang. In the early Pajajaran era, the cleaver had approached visual perfection after being perfected by famous Mpu, such as Empu Windu Sarpa, Mercukunda, and Ramayadi. As an object of creation, the cleaver cannot be separated from the fulfillment of ritual needs that have shifted to Javanese Hinduism. Apart from fulfilling ritual needs, the cleaver has evolved by itself as a complement to the values of Sundanese culture at that time. The development of the system and the unification of thought became the impetus to enrich the form of cleaver art, such as the forms that exist today.

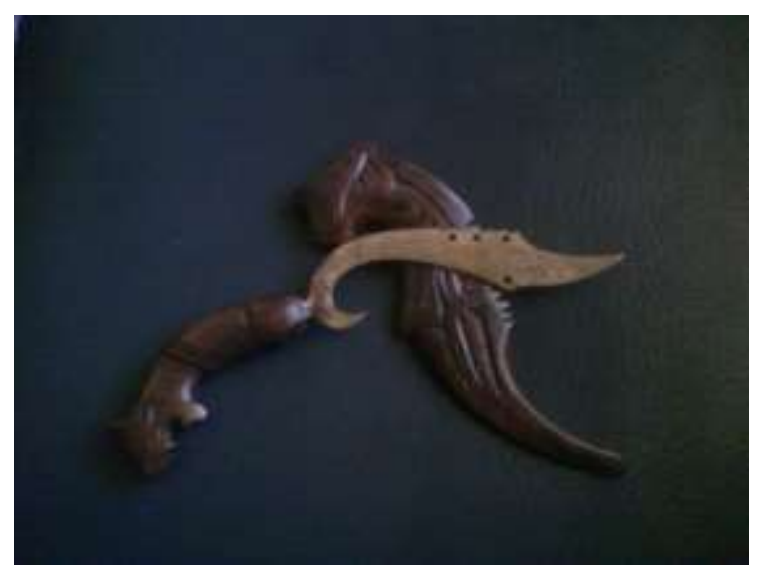

Source: Wikipedia

Kujang Symbol of West Java Province

It is estimated that in $1170 \mathrm{AD}$, the cleaver began to be used by early Pajajaran royal officials as heirlooms. The cleaver serves as a symbol of rank, respect for leaders, the value of a teaching and so on. According to some experts, the basic shape of the 
cleaver is a picture of the Pasundan area and parts of Java which also contains the Trimurti symbol (three holes).

In people's lives there is a different attitude towards the cleaver, it is because the community considers the cleaver to be mystical. In each area, there are generally a number of kris that are quite large, in contrast to the cleaver which is given a special attitude by the community. In a very symbolic cleaver ceremony, such as when going to cut rice, cut down trees, and so on, the cleaver only starts it and then cuts and cuts using sickles and axes. This explains that in society the cleaver is very symbolic and is treated specifically. According to some sources, the name and shape of the cleaver is taken from the Sundanese admiration for the kudhang or kidang or deer, which are agile, agile, have long and forked horns, which scare other animals.

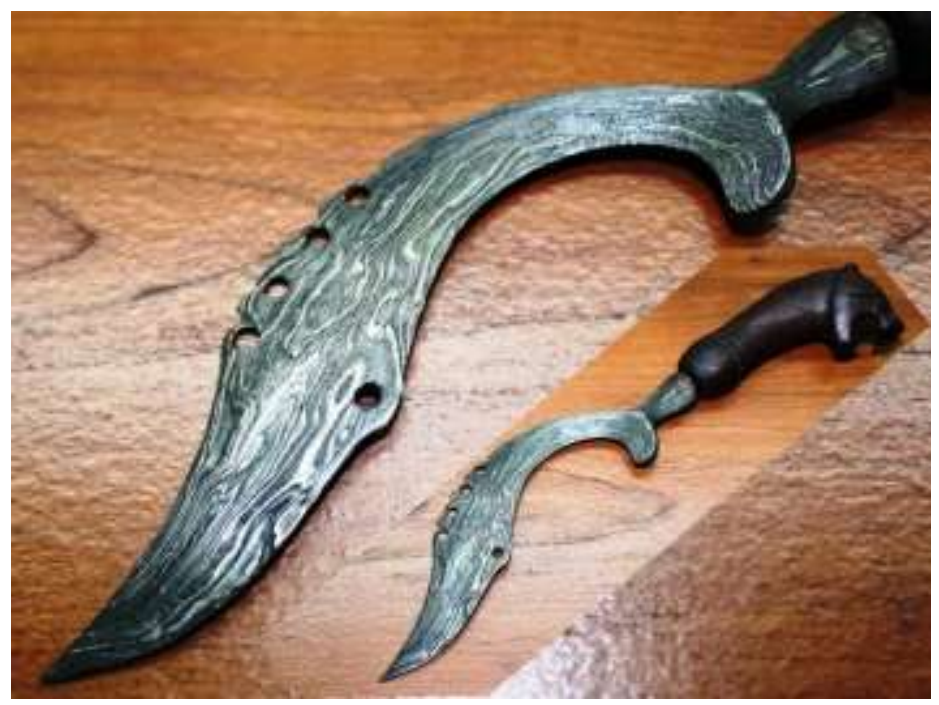

\section{Source: Wikipedia}

Kujang Symbol of West Java Province

Kujang is a traditional weapon typical of West Java whose shape is often used as batik motifs, statues, and symbols that reflect the Sundanese. Reporting from the official website of the Ministry of Education and Culture of the Republic of Indonesia, the term cleaver comes from the ancient Sundanese language "kudi" which means a weapon or amulet with supernatural powers and "hyang" which means god. So literally the cleaver can be interpreted as an amulet or weapon that has the magical power of a god in it. Aris Kurniawan in the Journal of Historical and Philosophical Studies of Kujang (2014) states that the cleaver has sacred and mystical values used as a mystical medium, a status symbol (rank), respect (to people who have contributed greatly to the kingdom), and amulets or heirlooms of high-ranking officials and nobles. Pajajaran work. Kujang is used as a multifunctional tool that cannot be separated from the life of the Sundanese people. The cleaver used by the people has a simple shape and is made of materials that are not too expensive. While the cleaver used by the higher-ups has expensive materials and luxurious designs.

The parts of the Kujang Kujang consist of four main parts, namely: Papatuk or congo is the part at the tip of the cleaver that is sharp and sharp. Silih or eluk is the body of a cleaver whose shape is curved like one side of a bird's wing that stretches out. The cistern is the prominent part of the cleaver's stomach. The eye is the hole in the cleaver. 
Kujang is not just a curved weapon. The cleaver is made by blacksmiths with various traditional rituals and is also maintained with traditional rituals. The cleaver is an aesthetic weapon that is shaped with unique and beautiful carvings, so the cleaver can be called a form of masterpiece of art.

\section{B. BASIC THOUGHTS}

Kujang is a human manifestation as the embodiment of the most perfect universe. Kujang is a philosophical value of divine teachings / guidelines or ageman about the origin of the universe which is used as the basis of a country based on noble religious values. Kujang form is a manifestation of human form as a perfect creation. Kujang form, is a manifestation of the universe which will later be written in Aji Saka Purwawisesa script in the Sang Saka Cretan language or Sanskrit (Sankskrit). The naming of the manuk as a symbol of state sovereignty is then personified in the form of a bird, and the bird is the only reason or background for the imagery. These symbols tend to be "abstract" far from reality, but to their rational and empirical patterns and structures. (Aris Kurniawan 2014)

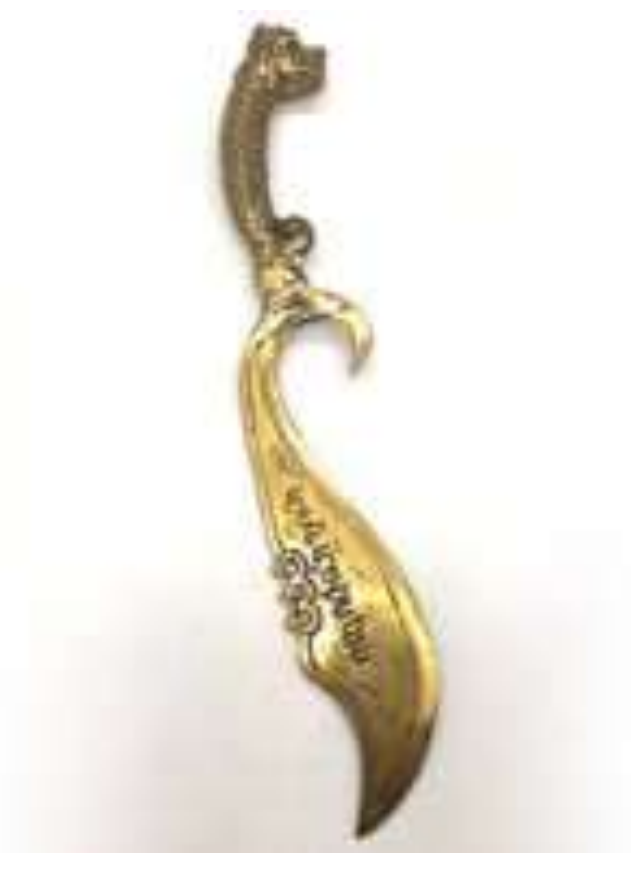

Source: Wikipedia

Kujang Symbol of West Java Province

The cleaver later became a symbol of the teachings of Galeuh-na Nu Agung or Galuh Hyang Agung (Galunggung) and the state system was symbolized as Galudra (Garuda) - Galuh Ratu Sunda. Kujang is a symbol of a concept of Sundanese teachings. Where the conception of the teachings above is abstract, the predecessors of this nation were able to implement it into a visual form, namely a cleaver weapon. Kujang has a long historical background, the process of its creation is widely discussed and studied in various previous studies.

Based on the evidence found, many of the cleavers are thought to have been made before the Pajajaran era. There are even cleaver researchers who state that the cleaver has existed since the time of the Taruma Nagara kingdom. Although the cleaver was never written in an inscription, there is a lot of evidence that supports its existence, such as; the 
megalithic site of the Batu Kujang mountain in the Sukabumi area, the discovery of kudi in the Batujaya Karawang temple complex, the reliefs of the Sukuh temple in Surakarta, Sir Stamford Raffles' notes in The History of Java and so on. Aris Kurniawan (2014)

According to the results of Slamet Kuntjoro's study, it is estimated that before metal technology was achieved during the Dongson culture or the bronze age, humans had created various basic forms of tools. Typical weapons or tools are made of flat stone, then due to technological developments, the basic raw materials are made of bronze. The tool is used as a cutting tool, slashing and can be thrown to hit the target of the game. This form of stone and bronze tools developed after wrought iron technology was mastered. Another opinion states that in the archipelago in general, "kudi" tools (in the form of resembling deer antlers) become hunting weapons and cutting tools.

\section{KUJANG}

Kudi is found in various regions in Indonesia, including; the islands of Alor, Java, Madura, Bali, Sumatra, Sulawesi and Kalimantan. It is said that khodiq on the island of Madura evolved as a common weapon called "calok" or kudi calok (calok Monteng) until it reached its shape (evolutively) which we now know as sickle or sickle. While on the island of Java in general, the kudi has evolved into a form of tool called a bendo sickle (kudi bendo) or sickle (functionally). Kujang (for the Pasundan area) is a weapon that has sacred and mystical values (a ritual tool).

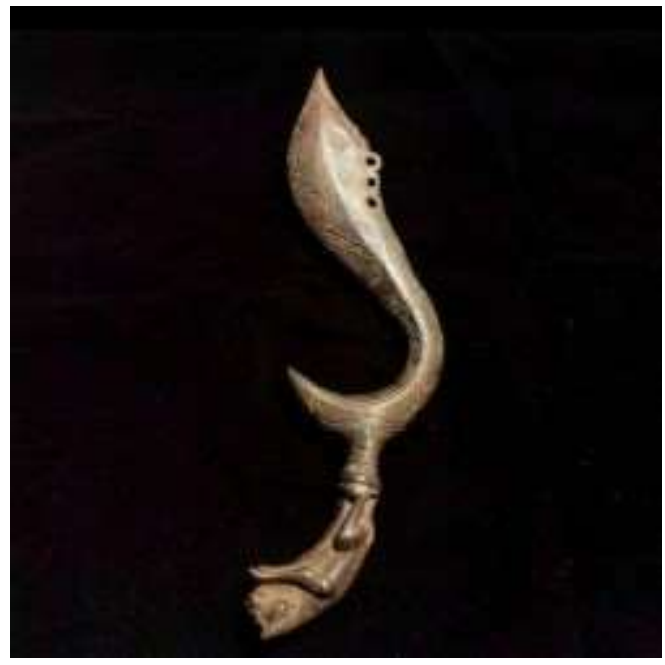

Source: jabar.suara. com

Kujang Symbol of West Java Province

It is very clear that the nail and cleaver developed different functions. Kudi became a functional tool in Java, maybe even the entire archipelago, while the cleaver was more specifically developed and evolved in the Pasundan area (Java Island in general?). Kujang functions as spiritual objects or better known as heirlooms and talismans. The multifunction of the kudi, among others, as a rice cutting tool (scythe), as a self-defense tool. While the cleaver serves as a mystical medium, a status symbol and a talisman (pajimatan) or sipat kandel (piandel).

At the time of Pajajaran Makukuhan or early Pajajaran (according to existing references) the cleaver had approached perfection in a visual way, after being designed or designed by famous Mpu such as Empu Windu Sarpa, Mercukunda, and Ramayadi. As an object of creation, the cleaver cannot be separated from fulfilling the needs of 
cultural rituals that have shifted to Javanese Hinduism. The cleaver was not only created to fulfill ritual needs, but also evolved as a complement to the values of Sundanese culture at that time.

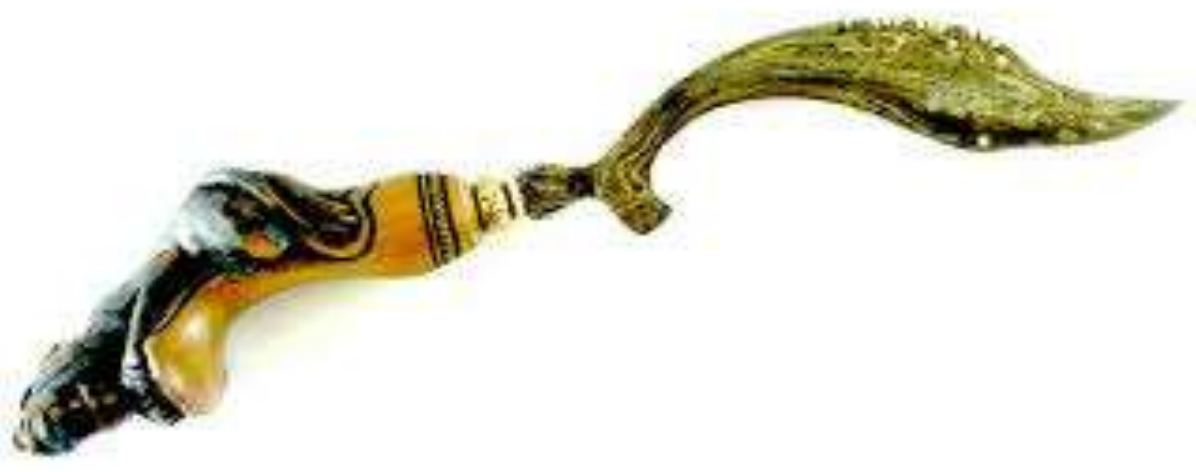

Kujang Symbol of West Java Province

Source: kompas.com

The development of the system in value or order and the unification of thought became the impetus to enrich the form of cleaver form, such as the forms found today. It is estimated that in $1170 \mathrm{AD}$, the cleaver as a talisman or heirloom (piandel) began to be used by officials and nobles of the Pajajaran Makukuhan kingdom. The cleaver serves as a symbol of rank status, respect for leaders who have contributed greatly to the country, the value of a teaching and so on (the reign of King Kuda Lalean). As a result of the relationship between the development of the constitutional system and the teachings of Sunda Wiwitan (Sunda tikkan or Sundanese adab) the form of a cleaver developed as an implementation of mapping the island of Java (Ku Jawa Hyang). That what is called the great magic of ancient people is still found in speech culture (oral).

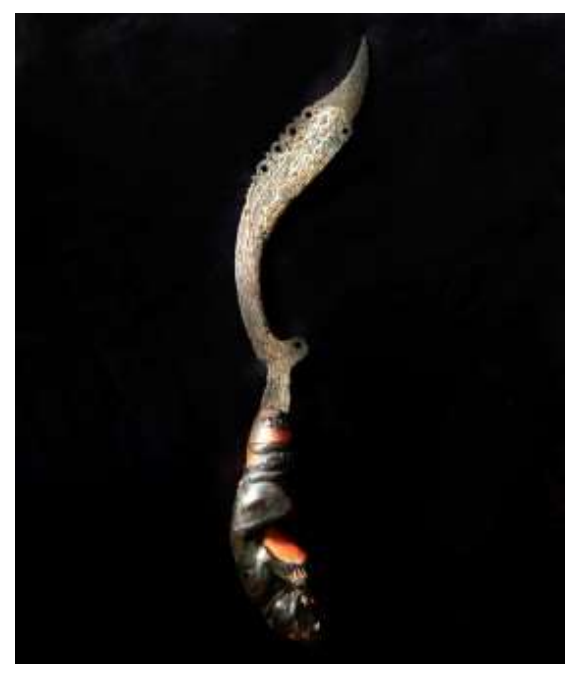

Kujang Symbol of West Java Province

Source: tribun.com 
Sunda cleaver Based on initial observations, it can be seen that the cleaver has a wealth of shapes and sizes. In various previous studies, this has not been studied in depth about the cleaver with this understanding. The diversity of the shape of the cleaver is very interesting to study more deeply. Kujang was originally a multi-functional tool and weapon. This is evidenced by the use of kudi and cleaver as tools in several areas such as the Banyumas (kudi) area, the traditional Pancer Pangawinan community in Cisolok, Sukabumi Regency, and Kanekes Banten Province. Based on the evidence of artifacts found in the Kanekes (Bedouin) area of Banten province, it turns out that the characteristics of the cleaver which is categorized as a multifunctional tool is very different in character from the cleaver which is a weapon (heirloom) of the Sundanese people.

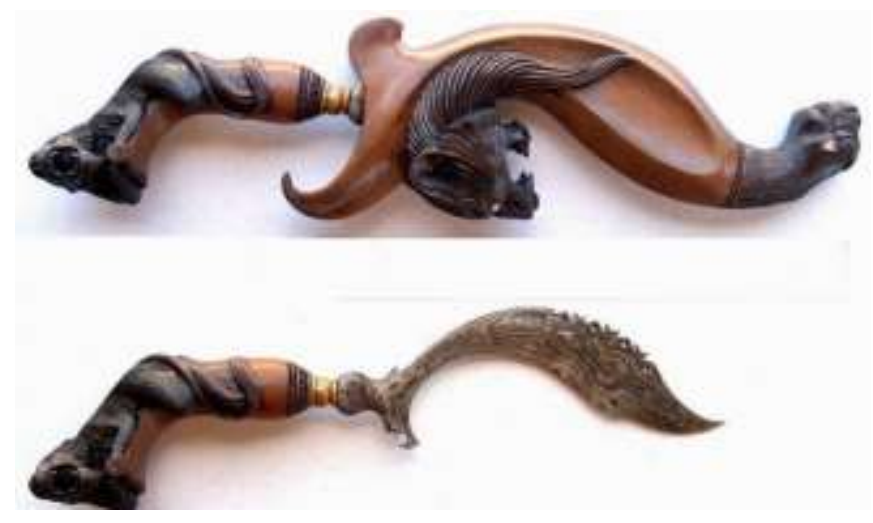

Kujang Symbol of West Java Province

Source: budaya.sukabumi.com

For the Kanekes community, the cleaver refers to a multi-functional tool, which is generally called a machete by people outside of Kanekes. Thus the cleaver referred to by the Kanekes community is a tool that only has a practical function or value, while the cleaver which is a Sundanese heirloom and the object in this study is an heirloom that has symbolic and philosophical values. This is very interesting for the author to conduct a deeper study, because the theory has become a reference (a cleaver as a multifunctional tool) and an understanding of society in general. The discovery of various variants of cleaver form from various regions in West Java as research samples, is increasingly interesting to explore further.

Although the cleaver is found in various areas in West Java, this does not mean that the cleaver represents the area where it was found and created in that area. Kujang cannot be equated with handicraft products that are characteristic of certain regions such as batik. Batik with the motif of the Ngibing Peacock is a characteristic of the Garut region and Batik Mega Mendung is the hallmark of Cirebon. Meanwhile the cleaver and several other types of tosan aji (which date back to the ancient period) are not like that. Kujang relates to something broader and more cosmological. Tracing the existence of a cleaver is a very challenging activity, and it is as if entering the wilderness of a foreign culture. In fact, there are a lot of cleavers that are no longer intact, and make the chain of history broken.

Finding various forms of cleavers is a matter of pride in itself, meaning that the cleaver as historical evidence has been saved. The naming and classification of the shape of the cleaver is also very diverse, so it is difficult to determine which one best fits the characteristics of the shape of the cleaver in question. While one form of kudi (the shape is the same as the old kudi) is still widely used by rural communities in the Cilacap, 
Banyumas, Purwokerto and surrounding areas. When compared with the naming of the kris (artificial discipline or style) of keris, such as Bango Dolog, Kuntul Ngantuk, Banyak Angrem, Kebo Theki and so on, the name is not always based on the similarity of the shape of the blade.

Bango Bolog's kitchen kris does not resemble a crane at all, and the kris with the sleepy egret's kitchen does not resemble an egret and Kebo Theki does not resemble a buffalo. In the discipline of naming in tosan aji (kris and tumbak) it does not always directly state the relationship with the form of the form. To understand and know the background of the different principles in naming the cleaver and other types of tosan aji, various knowledge related to tosan aji in general and Sundanese culture are needed. Sundanese cosmology as the basis for analyzing and studying the shape of the cleaver is expected to lead to an understanding of the value of form, naming, aesthetics, symbols and philosophical meanings contained in each blade of the cleaver. The phenomenon of the cleaver as a value is widely expressed in various Sundanese fairy tales such as, "Kujang at Hanjuang Siang Seven Ronggeng when Sirna", "Upload Kidang Down Kujang", "Kujang two Pangadekna or Pangadegna", "Kujang Keur naratas in the Nature of Authority", and others. Etc

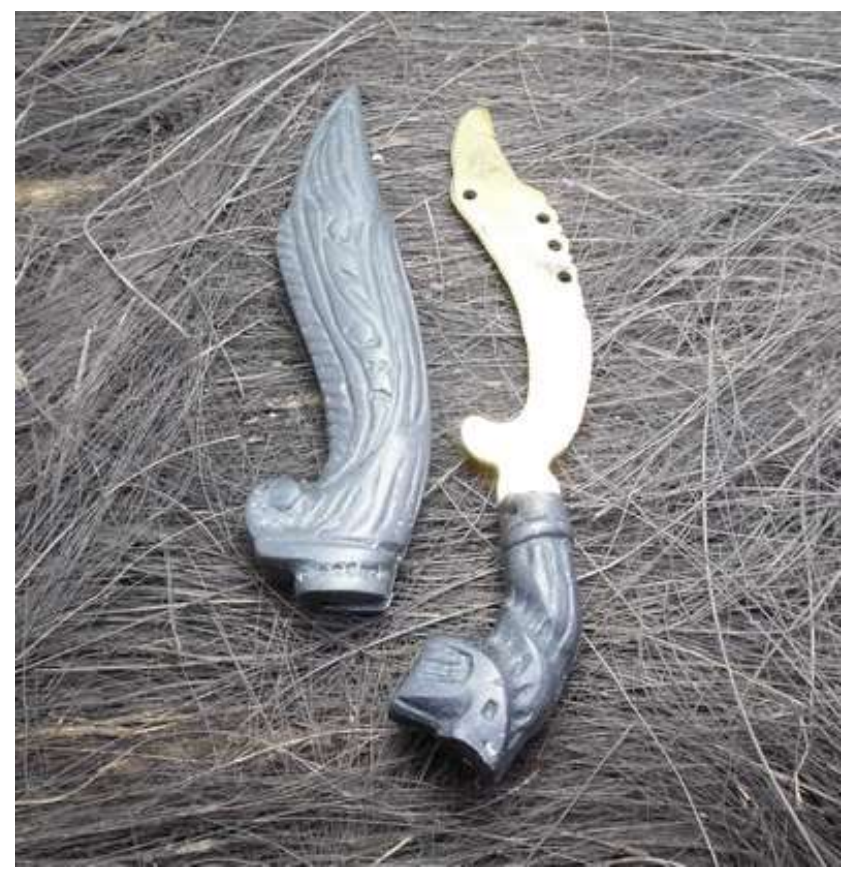

Kujang Symbol of West Java Province

Source: budaya.jawabarat.com

Cleaver Shape Morphology General understanding of cleaver and cleaver theory which is used as a morphological reference, has a strong tendency to name cleavers based on mimetic symptoms. In general, in Sundanese society, this phenomenon is commonly referred to as "siga" (resembling) in seeing various artistic phenomena. For example, the naming of the egret cleaver, because it is considered to resemble an egret's shape, Ciung's cleaver because it is considered to resemble a ciung bird and so on. With the analysis of the meaning of the cleaver above, the cleaver can be decomposed into the morphology of the cleaver form which is matched with the dynamics of the bird (manuk) form and the 
process of human birth and life, according to the interpretation contained in the Silib. The description of the morphology of the cleaver and the relationship of forms can be seen in the following figure.

Cleaver as a Picture of Territory of Power In the early Pajajaran Makukuhan or Pajajaran era, the cleaver was nearing perfection in visuals, after being designed or designed in the 4-7th century AD by famous MPUs such as Empu Windu Sarpa, Mercukunda, and Ramayadi. As an object of creation, the cleaver cannot be separated from fulfilling the needs of cultural rituals that have shifted to Javanese Hinduism. The cleaver was not only created to fulfill ritual needs, but also evolved as a complement to the values of Sundanese culture at that time. The development of the system in value or order and the unification of thought became the impetus to enrich the form of cleaver form, such as the forms found today. It is estimated that in $1170 \mathrm{AD}$, the cleaver as an amulet or heirloom (piandel) began to be used by high-ranking officials and nobles of the Pajajaran Makukuhan kingdom.

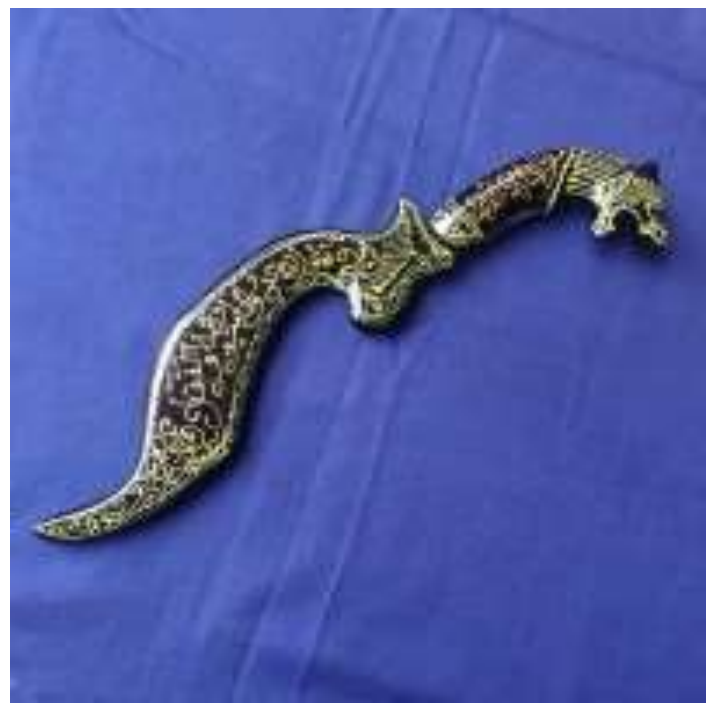

Kujang Symbol of West Java Province

Source: budaya.jawabarat.com

The cleaver serves as a symbol of rank status, respect for leaders who have contributed greatly to the country, the value of a teaching and so on (the reign of King Kuda Lalean)[9]. As a result of the relationship between the development of the constitutional system and the teachings of Sunda Wiwitan (Sunda tikkan or Sundanese adab) the form of a cleaver developed as an implementation of mapping the island of Java (Ku Jawa Hyang). That what is called the great magic of ancient people is still found in speech culture (oral).

The note was found and confirmed by Alexander Lee, an occult expert and professor of metaphysics from America, the note stated, among other things, that in one of his ascetics, Prabu Kudo Lalean during the Pajajaran Makukuhan kingdom found a visual picture or vision of the shape of the earth. which he stepped on now. So Kudo Lalean asked for an examination of the visual experts. Master Windu Sarpo also confirmed what was found visually by Prabu Kudo Lalea, namely the visualization of the island of Java" (Ku Jawa Hyang). Then after that, the mandate was handed over to Mpu 
Windu Sarpo according to the results of his exploration of the shape of the island "Java Dwipa".

Another note was disclosed by Sulaeman Kapanradja from Ciledug Garut who researched kudi and cleavers. Sulaeman Kapanradja found several ancient Javanese scripts which stated: “...A cleaver called the great cleaver of Prabu Wangi or Sang Nata (the king of Pasundan who died in the Bubat war scandal in 1357 AD), is in the form of a map of Sunda land (not the island of Java), the area is up to Central Java region. The cleaver depicts Ujung Kulon, Banten Bay, Pelabuhan Ratu and others.

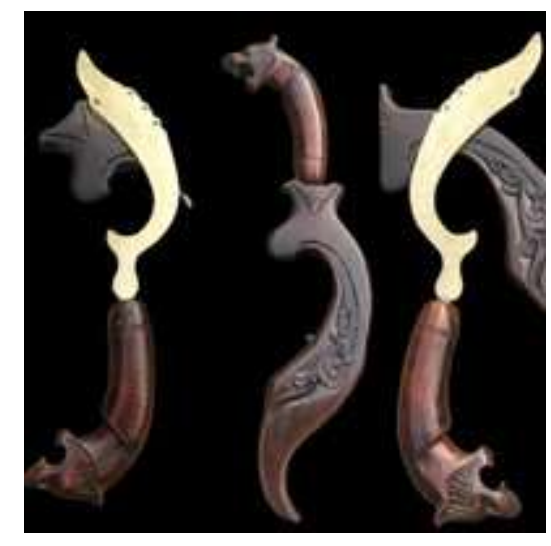

Kujang Symbol of West Java Province

Source: budaya.jawabarat.com

Solomon's opinion is different from the previous two opinions. However, the basic form of the cleaver is correct as a depiction of the shape of a map of the Pasundan area or the island of Java. That the cleaver is a map form which also contains the Trimurti symbol (three holes), is close to reasoning. However, another opinion states, because the agrarian world is agriculture where rice is the main one. As is well known, the Karawang area is the granary of West Java, and sites that indicate the existence of the Sunda kingdom (Batu Jaya Temple, Karawang during the Taruma Nagara period) were found The aesthetic form of the cleaver may be a complement to the ritual depiction of a bird as a symbol of enlightenment (silib-siloka in Sundanese). Moreover, if you look at the slender cleaver, the pangarak (in some areas it is popularly known as the term "Cangak") can be considered to represent the shape of the bird.

The relics of the ancient beauty are certain to be worked on by a master or teacher. Snouck Hurgronje, Hazeu, Kern, and G.P. Rouffaer in 1909 reported his research on the kudi as an ancient sharp weapon in Madura and in Central Java (Purwokerto Banyumas). Actually, their observations are very close to the truth and very critical. That the kudi disappeared and developed into a new form of kudi, while the cleaver became a ceremonial heirloom and a symbol for kings. The new form of weapon is called Kudi Hyang, in the sense of a "holy" (sacred) kudi specifically for ceremonies or personal holdings or piandel.

It turns out that it is precisely the kudi that are actually used as weapons or furniture for agricultural tools, while the Kudi Hyang or Kudi Hiyang (Kudyang) are never used carelessly except for self-preservation. Agricultural tools have never had a prestige. A tool of war or a weapon whose blade has prestige. So the sources that mention magic weapons are quite a lot. However, sources that tell how the weapon was made, how to 
use panday, what kind of iron, what knowledge and so on, are very minimal. Metals that are often referred to are gold, silver, iron, steel, tin.

\section{CLOSING}

In general, the cleaver has the meaning of an heirloom that has aesthetic value which has philosophical and symbolic meaning of Sundanese culture. Where these values and meanings have a certain mystical power that comes from Hyang Tunggal. As a wesi aji or heirloom from the past until now the cleaver occupies a very special position in Sundanese society. which is out of the context of the way people express themselves. Thus, the method or approach used in uncovering the intrinsic dimensions of Sundanese artifacts such as the Sunda Buhun (Old Sundanese) Palintangan Science based on the Sanskrit Script discipline or $\mathrm{Ha} \mathrm{Na} \mathrm{Ca} \mathrm{Ra}$ Ka (cacarakan) based on the Jendra Hayuningrat Literature book, Three Sunda Patterns (Sundanese Cosmology)., Pancaniti or Five Titian Sciences, Sundanese Aesthetic Concepts on Kujang, Kujang Visual Concepts, are the correct and relevant methods or approaches in the context of eastern philosophy, as well as philosophy of art. This is because the method or approach is based on the life guidance of the Sundanese people, which is their way of philosophizing, building knowledge and explanatory power, building an aesthetic distance, as well as being critical, with the artifacts of their own cultural heritage.

\section{BIBLIOGRAPHY}

Aris Kurniawan 2014) "Kajian Historis dan Filosofis Kujang”. Jurnal itenas purwarupa No.1 Vol. 2 Bandung : Itenas

Arthur S. Nalan (2000). Sanghyang Raja Uyeg: dari sakral ke profan. Humaniora Utama Press. ISBN 97-992-3137-X

Atmadja, D.K 2003-2009: Ilmu Palintangan Sunda Buhun (Sunda Lama) berdasarkan disiplin Aksara Sansakerta atau $\mathrm{Ha} \mathrm{Na} \mathrm{Ca} \mathrm{Ra} \mathrm{Ka} \mathrm{(cacarakan)} \mathrm{berdasarkan} \mathrm{kitab}$ Sastra Jendra Hayuningrat, Pola Tiga Sunda (Kosmologi Sunda), Pancaniti atau Lima Titian Ilmu, Konsep Estetika Sunda Pada Kujang, Konsep Perupaan Kujang. Makalah tidak dipublikasikan

Brahmanto Anindito (2015). Tiga Sandera Terakhir. Noura Books. ISBN 60-209-8947$\mathrm{X}$

Djati Sunda, Anis (2009). Pantun Bogor, www.bogor.net, diakses pada 21 Juni 2009

Edi Setiadi Putra (2011). "Interpretasi Visual terhadap Bentuk dan Fungsi Kujang Huma Pamangkas dengan Uji ANOVA (Analysis Of Variance) dan VAS (Visual Analog Scale)". Institut Teknologi Nasional. Diakses tanggal 21 February 2017

Februari 2011 [10] http://www.prigsbee.com/maps/indon-java.htm, diakses 21 Juni 2011 http://www.raremaps.com/gallery/detail/0239gh

Intan Mardiana N, Endang Sriwigati, Yuni Astuti Ibrahim \& Andini Perdana (2009). Agus Aris Munandar, ed. Koleksi Pilihan 25 Museum di Indonesia. Direktorat Jenderal Kebudayaan. 5156648

Kuntjoro, Slamet, (2000), Kujang, Tinjauan Eksoteri dan Isoteri, Malajalah Pamor, Jakarta

Kurniawan, Aris (2011), Kajian Filosofis dan Simbolik Kujang, Tesis, Program Pascasarjana Seni Rupa ITB, Tesis, Program Pascasarjana SeniRupa ITB 
"KUJANG". Direktorat Warisan dan Diplomasi Budaya. 2015-12-17. Diakses tanggal 2020-07-11.

Kerjasama Pusat Kajian Lintas Budaya 2011, hlm. 62 "Kujang, Senjata Tradisional Indonesia". House Sangkuriang Bandung (dalam bahasa Inggris). Diakses tanggal 2020-07-11.

.Luxamore (2001) Kujang, The Talismanic Sickle, http://www.indotalisman.com/Kujang.html, diakses

Raffles, Thomas Stamford, (2008), The History of Java, Narasi: Yogyakarta / Nouvelle_Carte_De_LIsle_De_Java/Schley.html diakses Juni 2011 [12] Horgronje ,C Snouck (1904) : Iets Over Koedi en Badi, TBG 47;387- 397. Batavia : Albrecht \&Co de Vries, Hubert. "JAWA BARAT". hubert-herald.nl. Diakses tanggal 202007-11.

Setiawan, Budi (2009), Guaran Kujang: Diskusi dan Presentasi Kujang, Seminar di Common Room Bandung, 20 November 2009.

Sumardjo, J. (2006): Pendekatan Budaya Atas Seni Rupa Tradisi Budaya Etnik Indonesia dalam MetodologiPenelitian Seni, Ira Adriati (ed.), MetodologiPenelitian Seni, Departemen Seni Murni, Fakultas Seni Rupa dan Desain, ITB.

Suryadi, (2008), Kujang Sebagai Pusaka Tradisi Sunda Tinjauan Estetika dan Simbolik

Sukanda-Tessier, Vivian, (1984) Notes on Sabrang, I.E Country on the Other Side of The Sea in Classical Sundanese Literature, SPAFA Consultative Workshop or Research into Maritime History \& Trade Networks, Indonesia

Saleh Danasasmita \& Anis Djatisunda (1986). Kehidupan masyarakat Kanekes. Bagian Proyek Penelitian dan Pengkajian Kebudayaan Sunda (Sundanologi), Direktorat Jendral Kebudayaan, Departemen Pendidikan dan Kebudayaan. OCLC 6801889. Pemerintah Negara Pasundan 1949, hlm. 139

Widya Dharma Agama Hindu SMP kls 9. Ganeca Exact. hlm. 94. ISBN 978-979-744740-3. 